\title{
Soil Nutrient Management Practices Influence the Carotenoid Content and Profile of Orange Fleshed Sweet Potato Variety (UMUSPO 3)
}

\author{
Ojimelukwe Philippa $C^{1, a *}$, Okpanku Udo $U^{1, b}$
}

\begin{abstract}
1'Department of Food Science and Technology, Michael Okpara University of Agriculture, Umudike email: ${ }^{*}$ ojimelukwe.philippa@mouau.edu.ng; ${ }^{1 *}$ philippaco60@gmail.com (corresponding author); budoumah@gmail.com
\end{abstract}

Keywords: Soil nutrient management; carotenoid content and profile, Orange fleshed sweet potato

\begin{abstract}
Food bio fortification holds a lot of promise for the alleviation of hidden hunger. The appropriate soil nutrient management methods that will maximize the pro vitamin A content of bio fortified Orange fleshed sweet potatoes (OFSP) (Umudike Sweet Potato Orange-fleshed 3) was evaluated in the present research. The carotenoid content and profile of OFSP variety grown on soils given five different nutrient managements were compared. The soil management treatments given were: $\left(\mathrm{VB}_{1}\right)$ Poultry manure at $5 \times 10^{3} \mathrm{~kg} / \mathrm{ha}$ (control); $\mathrm{VB}_{2}$ : Poultry manure at $2.5 \times 10^{3} \mathrm{~kg} / \mathrm{ha}+\mathrm{NPK}$ at $200 \mathrm{~kg} / \mathrm{ha}+$ Agrolyser at $2.7 \mathrm{~kg} / \mathrm{ha}, \mathrm{VB}_{3}$ : Agrolyser at $2.7 \mathrm{~kg} / \mathrm{ha}+\mathrm{NPK}$ at $200 \mathrm{~kg} / \mathrm{ha}$; $\mathrm{VB}_{4}$ : Poultry manure at $5.0 \times 10^{3} \mathrm{~kg} / \mathrm{ha}+\mathrm{NPK}$ at $200 \mathrm{~kg} / \mathrm{ha}, \mathrm{VB}_{5}: \mathrm{NPK}$ 15:15:15 at $400 \mathrm{~kg} / \mathrm{ha}$. (Agrolyser: $\mathrm{Ca}-20.4 \% ; \mathrm{Na}-1.04 \% ; \mathrm{Zn}-0.11 \%, \mathrm{~S}-2.72 \%$; Fe, Mn, Mo trace) (NPK 15:15:15 was used in all cases).

Carotenoids were extracted from the potato samples and analyzed using High performance Liquid Chromatography (HPLC). The best treatment that promoted high pro vitamin A carotenoid content was soil treatment with Poultry manure $\left(5 \times 10^{3} \mathrm{~kg} / \mathrm{ha}+\mathrm{NPK}(200 \mathrm{~kg} / \mathrm{ha})\right.$. This soil treatment led to the highest contents of $\alpha$-carotene $(6.14 \mu \mathrm{g} / \mathrm{g}) ; 13-$ cis- $\beta$-carotene $(12.36 \mu \mathrm{g} / \mathrm{g})$; All-trans- $\beta$-carotene $(87.89 \mu \mathrm{g} / \mathrm{g})$ and 9 -cis- $\beta$-carotene $(2.99 \mu \mathrm{g} / \mathrm{g})$. The best soil management treatment for the highest yield of $\beta$-cryptoxanthin $(7.95 \mu \mathrm{g} / \mathrm{g})$ was poultry manure at $2.5 \mathrm{~kg} / \mathrm{ha}+\mathrm{NPK}$ at $200 \mathrm{~kg} / \mathrm{ha}$.
\end{abstract}

\section{Introduction}

Vitamin A deficiency (VAD) is considered a serious problem of public health significance in over 70 countries. Countries of South-East Asia have the highest prevalence of VAD (49.9\%) followed by Africa, where $44.4 \%$ of preschool-age children and $13.5 \%$ of pregnant women suffer from vitamin A deficiency [1]. It is an essential micronutrient for normal immune function of the body. It is essential for good health and eyesight [2]. The dietary sources of vitamin A are preformed vitamin A which comes from animal origin (such as fish oils, liver, milk, eggs and butter) that contain vitamin A in its true form (also called retinol) which can be used directly and easily by the human body and also pro-vitamin A carotenoids (found in yellow and orange-fleshed fruit and vegetables and in dark-green leafy vegetables) [3, 4]. Of the approximately 600 carotenoids found in nature, only three are important precursors of vitamin A in humans beings viz, $\beta$-carotene, $\alpha$-carotene and $\beta$ cryptoxanthin [5] and $\beta$-carotene is the major pro-vitamin A of most carotenoid containing foods [6]. Recent studies associated with the consumption of carotenoid rich food showed the decrease of the incidence of certain cancers in human beings [7]. Food fortification, food bio-fortification, dietary diversification and vitamin A supplementation are the recommended strategies to control vitamin A deficiency [8]. Orange-Fleshed Sweet Potato (OFSP) forms an important source of carotene rich food $[9,10]$. Jailal et al. [11] suggested that a food based approach may be a successful way of reducing the prevalence of vitamin A deficiency [12]. One medium sized OFSP (depending on the carotenoid content of the OFSP) is said to provide about twice the $\beta$-carotene needed for the recommended daily requirement of vitamin A. Vitamin A deficiency prevents people from surviving and thriving as 
productive members of society and stagnates countries in a cycle of poor nutrition, poor health, lost productivity, persistent poverty, and reduced economic growth [13].

Sweet potato, (Ipomea batatas Lam.), is an important staple food crop in Nigeria [14]. It grows fast and requires low work input. Sweet potato is often planted in Africa as a security crop or famine prevention crop [10]. The main sweet potato producers are China, Indonesia, Vietnam, India, Philippines and Japan in Asia, Brazil and the USA the Americas and Nigeria, Uganda, etc [15]. It has the potentials to improve household and national food security, health and livelihoods of poor families in sub-Saharan Africa [16]. It is an important alternative source of carbohydrates consumed in the country as an energy giving food and attains the fourth position after rice, corn and cassava. Presently, this crop is considered as having low economic value but it has significant social importance. It is very popularly used as snack food, but it is also used as staple food or as a rice substitute in many countries [17]. It is high in carbohydrate and vitamin A contents (some varieties) and can produce more edible energy per hectare per day than wheat, rice, or cassava. The roots may be processed into starch, candy, flour and alcohol. The leaves are edible (Belehu, 2003) [18]. Figure 1 shows UMUSPO3 Orange fleshed sweet potato variety.

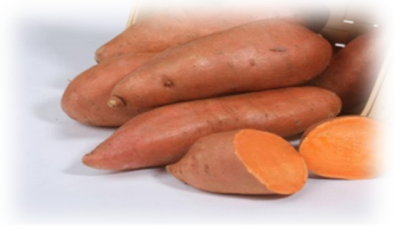

Figure1. UMUSPO 3 Orange-fleshed sweet potato variety

\section{Field Work, Experimental Design and Treatments}

The field work was carried out by the agronomy students of Michael Okpara University of Agriculture, Umudike. The sweet potato variety (UMUSPO 3) was planted at the National Root Crops Research Institute, experimental farm, Umudike, Abia State, Nigeria (situated between latitude $05^{\circ} 29 \mathrm{~N}$ and longitude $07^{\circ} 33 \mathrm{E}$ and $122 \mathrm{~m}$ altitude). The soil is sandy loam, $78.8 \%$ sand, $6.8 \%$ silt, $14.4 \%$ clay, $\mathrm{pH} 4.7,1.59 \%$ organic matter, $0.08 \%$ Nitrogen $(\mathrm{N}) ; 32.1 \mathrm{mg} / \mathrm{kg}$ Phosphorus $(\mathrm{P})$, and 0.35 $\mathrm{mg} / \mathrm{kg}$, Potassium (K) (as determined using standard AOAC methods). The treatments were arranged in randomized complete block design with three replications. The main plot treatment was one variety (UMUSPO 3) of Orange-Fleshed Sweet Potatoes (OFSP). The treatments were five nutrient combinations with control. $\left(\mathrm{VB}_{1}\right)$ Poultry manure at $5 \times 10^{3} \mathrm{~kg} / \mathrm{ha}$ (control); $\mathrm{VB}_{2}$ : Poultry manure at $2.5 \times 10^{3} \mathrm{~kg} / \mathrm{ha}+\mathrm{NPK}$ at $200 \mathrm{~kg} / \mathrm{ha}+$ Agrolyser at $2.7 \mathrm{~kg} / \mathrm{ha}, \mathrm{VB}_{3}$ : Agrolyser at $2.7 \mathrm{~kg} / \mathrm{ha}+\mathrm{NPK}$ at $200 \mathrm{~kg} / \mathrm{ha} ; \mathrm{VB}_{4}$ : Poultry manure at $5.0 \times 10^{3} \mathrm{~kg} / \mathrm{ha}+\mathrm{NPK}$ at $200 \mathrm{~kg} / \mathrm{ha}, \mathrm{VB}_{5}: \mathrm{NPK}$ 15:15:15 at $400 \mathrm{~kg} / \mathrm{ha}$. (Agrolyser: $\mathrm{Ca}-20.4 \%$; $\mathrm{Na}-1.04 \% ; \mathrm{Zn}-0.11 \%, \mathrm{~S}-2.72 \%$; Fe, Mn, Mo trace) (NPK 15:15:15) was used in all cases.

Chemical analysis showed that the poultry manure (measured using standard AOAC methods) had values of $\mathrm{pH} 7.06, \mathrm{~N} 2.17 \%, \mathrm{P} 1.06 \%$ and $\mathrm{K} 0.62 \%$ as the total content of samples. The poultry manure were applied into appropriate plots after ridging while NPK were applied 4 weeks after planting by band placement. Each sub-plot measured $3 \mathrm{~m} \mathrm{x} 2 \mathrm{~m}\left(6 \mathrm{~m}^{2}\right)$. Sweet potato vine cuttings of $20 \mathrm{~cm}$ length with at least 4 nodes were planted during the rainy season (Mid July) at a distance of $30 \mathrm{~cm}$ apart, along the crest of the ridges. Supply of vacant stands was done at 2 weeks after planting.

\section{Determination of Carotenoids}

The analysis of the $\beta$-carotene in sweet potato samples was carried out at the Crop Utilization Unit (Laboratory) of International Institute of Tropical Agriculture (IITA) Ibadan. The method of Rodriguez-Amaya and Kimura [19] was used.

Sample preparation: Fresh sweet potato tubers (UMUSPO 3) were selected randomly and washed with clean water. They were peeled, washed and sectioned into four longitudinally. Two opposite 
sections from each tuber were taken, sliced into small pieces $(1 \mathrm{~cm})$ and mixed manually. They were packaged in aluminum foil, labeled and stored at $-80^{\circ} \mathrm{C}$ in a deep freezer.

Extraction: Carotenoids were extracted by grinding about $3 \mathrm{~g}$ of each sample in a mortar and pestle with about $50 \mathrm{ml}$ of cold acetone. The residue was filtered in a Buchner funnel layered with a filter paper (Whatman No. 42 filter paper). The residue was returned to the mortar and the extraction was repeated using $20 \mathrm{ml}$ acetone until the residue was nearly colourless. The total extract was transferred into a separating funnel $(250 \mathrm{ml})$ containing $20 \mathrm{ml}$ of petroleum ether. One litre of distilled water was used to wash the organic phase which separated from the aqueous phase. The aqueous phase was discarded. The organic phase was again washed with dilute brine solution to break-up any formed emulsions. The organic phase was collected through anhydrous Sodium sulphate (15 g) into a $25 \mathrm{ml}$ flat bottom flask. Ten (10) $\mathrm{ml}$ of the sample extract was concentrated with a rotary evaporator (Buchi Waterbath B-481 Switzerland) and dried under vacuum, for reverse-phase HPLC determinations of the various carotenoid fractions.

HPLC analysis: The modified method of Howe and Tanumihardjo [20] was used for the HPLC analysis. A quantity of $15 \mathrm{ml}$ of the freeze dried samples was reconstituted in methanol/dichloroethane $(1 \mathrm{ml}, 50: 50 \mathrm{v} / \mathrm{v})$ and $50 \mu \mathrm{l}$ was injected into the HPLC. A water HPLC system (Water Corporation, Milford, MA) consisting of a guard column, C30YMC carotenoid column ( $4.6 \times 250 \mathrm{~mm}, 3 \mu \mathrm{m})$ water 626 binary HPLC pump, 717 auto sampler and a 2996 photodiode array detector was used for carotenoids quantification. Solvent A was $100 \%$ methanol, while solvent B was $100 \%$ methyl tert-butyl ether (MTBE). Isocratic elution was carried out at $1 \mathrm{ml} / \mathrm{min}$ while the run time was $15 \mathrm{~min}$.

Spectrophotometric reading and calculation: Absorbance of carotenoid ether extract was taken at $450 \mathrm{~nm}$ using a spectrophotometer. The formula described by Rodriguez-Amaya and Kimura [19] was used to quantify the carotenoid content:

$$
\mathrm{C}_{\mathrm{x}}(\mu \mathrm{g} / \mathrm{g})=\frac{\mathrm{A}_{\mathrm{x}} \times \mathrm{C}_{\mathrm{s}}(\mu \mathrm{g} / \mathrm{ml}) \times \text { total Vol. of extract }(\mathrm{ml})}{\mathrm{A}_{\mathrm{s}} \times \text { sample weight }(\mathrm{g})}
$$

Where:

$\mathrm{C}_{\mathrm{x}}=$ Concentration $(\mu \mathrm{g} / \mathrm{g})$ of carotenoid

$\mathrm{A}_{\mathrm{x}}=$ Peak Area of the carotenoid

$\mathrm{C}_{\mathrm{s}}=$ Concentration of standard

$\mathrm{A}_{\mathrm{s}}=$ Peak area of the standard

The standard curve already established for the HPLC was used. The remaining $15 \mathrm{ml}$ sample extract was used to determine the total carotenoids spectrophotometrically.

The absorbance was measured at $450 \mathrm{~nm}$ in a spectrophotometer. The total carotenoids content was calculated with the formula

Total carotenoids content $(\mu \mathrm{g} / \mathrm{g})=\frac{\mathrm{A} \times \text { Vol. }(\mathrm{ml}) \times 10^{4}}{\mathrm{~A}^{1 \%} \times \text { sample weight }(\mathrm{g})}$

Where:

$\mathrm{A}=$ Absorbance

Vol. $=$ Total volume of extract $(25 \mathrm{ml})$

$\mathrm{A}^{1 \%}=$ Absorption coefficient of $\beta$-carotene in PE (2592)

The result was multiplied by 100 to obtain the carotenoid content in $\mu \mathrm{g} / 100 \mathrm{~g}$. All sample preparations, extractions and analysis were performed under white fluorescent lighting.

\section{Data Analysis}

Analysis of variance and multiple range test were used for the determination of significant differences $(p<0.05)$ among treatment means and separation of means was carried out using the SPSS 
17 software. Separation of means was carried out by Duncan Multiple range test and values were reported as means and standard deviation.

\section{Pro-Vitamin A Content of UMUSPO 3 Ipomea Batatas Variety (FW)}

Table 2 shows the Pro-vitamin A carotenoids and retinol equivalents of UMUSPO 3 Ipomea batatas variety.

Pro-vitamin A carotenoids: $\beta$-cryptoxanthin had the mean values of $6.41 \mu \mathrm{g} / \mathrm{g}$ was highest $(7.95 \mu \mathrm{g} / \mathrm{g})$ in the sample grown on soil treated with poultry manure at $2.5 \times 10^{3} \mathrm{~kg} / \mathrm{ha}$ plus NPK at $200 \mathrm{~kg} / \mathrm{ha}$ plus Agrolyser at $2.7 \mathrm{~kg} / \mathrm{ha}\left(\mathrm{VB}_{2}\right)$. This was significantly different $(\mathrm{p}<0.05)$ from other samples. The lowest value $(3.09 \mu \mathrm{g} / \mathrm{g})$ was obtained from Ipomea batatas planted on poultry manure treated soil at $5.0 \times 10^{3} \mathrm{~kg} / \mathrm{ha}\left(\mathrm{VB}_{1}\right)$. $\quad \beta$-cryptoxanthin exhibit $50 \%$ pro-vitamin A activity of $\beta$-carotene $[21,22]$. $\alpha$-carotene contents of the samples varied significantly $(p<0.05)$ with treatments. The highest value $(6.14 \mu \mathrm{g} / \mathrm{g})$ was from the sample grown on soil treated with poultry manure at $5.0 \times 10^{3} \mathrm{~kg} / \mathrm{ha}$ plus NPK at $400 \mathrm{~kg} / \mathrm{ha}\left(\mathrm{VB}_{4}\right)$, while the Ipomea batatas grown on soil treated with Agrolyser at $2.7 \mathrm{t} / \mathrm{ha}$ plus NPK at $200 \mathrm{~kg} / \mathrm{ha}\left(\mathrm{VB}_{3}\right)$ had the lowest value $(2.5 \mu \mathrm{g} / \mathrm{g}) . \alpha$-carotene has an unsubstituted $\beta$-ring and nine conjugated double bonds thus it exhibits half of the pro-vitamin $A$ activity of $\beta$-carotene $[19,23]$.

13-Cis- and 9-Cis- $\beta$-carotene values varied significantly $(\mathrm{p}<0.05)$ with different soil nutrient managements. The highest carotenoid contents were $12.36 \mu \mathrm{g} / \mathrm{g}$ and $2.99 \mu \mathrm{g} / \mathrm{g}$ for 13 -Cis- $\beta$-carotene and 9-Cis- $\beta$-carotene respectively obtained from Ipomea batatas planted on soil treated with poultry manure at $5.0 \times 10^{3} \mathrm{~kg} / \mathrm{ha}$ plus NPK at $200 \mathrm{~kg} / \mathrm{ha}\left(\mathrm{VB}_{4}\right)$.

Nitrogen fertilizer application above $80 \mathrm{~kg} \mathrm{~N} / \mathrm{ha}$ has been reported as not beneficial for beta -carotene yield for many sweet potato varieties $(\mathrm{P}>0.05)$ except for CIP Tanzania [22]. This research indicates that for UMUSPO3 OFSP, nitrogen levels above $80 \mathrm{~kg} \mathrm{~N} /$ ha are beneficial. Beta-carotene rich sweet potatoes have the potential to improve vitamin A status among the vulnerable groups in developing countries [22]. Marked variations have been observed in chemical constituents of sweet potato varieties [24]. These variations are invariably influenced by soil nutrients. Kalu et al. [25] investigated the effect of planting distance and harvest period on the carotenoid retention of this same sweet potato variety (UMUSPO3). A planting distance of $40 \mathrm{~cm}$ apart supported the maximum yield of 13-cis-beta carotene. This OFSP variety has also been found to be rich in carbohydrates and reducing sugars [26].

Table 2. Effect of different nutrient management treatments on pro-vitamin A content of UMUSPO 3 Ipomea batatas variety (FW)

\begin{tabular}{|c|c|c|c|c|c|}
\hline & $\mathbf{V B}_{1}$ & $V_{B_{2}}$ & $V_{B_{3}}$ & $\mathrm{VB}_{4}$ & $\mathrm{VB}_{5}$ \\
\hline $\begin{array}{l}\beta \text {-cryptoxanthin } \\
(\mu \mathrm{g} / \mathrm{g})\end{array}$ & $3.091^{\mathrm{e}_{\mathrm{e}}} \pm 0.00$ & $7.95^{\mathrm{a}} \pm 0.01$ & $5.93^{\mathrm{d}} \pm 0.01$ & $7.32^{\mathrm{c}} \pm 0.06$ & $7.76^{\mathrm{b}} \pm 0.02$ \\
\hline $\begin{array}{l}\alpha \text {-carotene } \\
(\mu \mathrm{g} / \mathrm{g})\end{array}$ & $3.41^{b_{ \pm}} \pm 0.04$ & $3.17^{\mathrm{d}} \pm 0.01$ & $2.56^{\mathrm{e}} \pm 0.01$ & $6.14^{\mathrm{a}} \pm 0.10$ & $3.28^{\mathrm{c}} \pm 0.01$ \\
\hline $\begin{array}{l}\text { 13-Cis- } \beta \text {-carotene } \\
(\mu \mathrm{g} / \mathrm{g})\end{array}$ & $10.81^{b} \pm 0.13$ & $3.56^{\mathrm{d}} \pm 0.04$ & $3.17^{\mathrm{e}} \pm 0.04$ & $12.36^{\mathrm{a}} \pm 0.21$ & $3.92^{\mathrm{c}} \pm 0.04$ \\
\hline $\begin{array}{l}\text { All-Trans- } \beta \text {-carotene } \\
(\mu \mathrm{g} / \mathrm{g})\end{array}$ & $64.25^{\mathrm{e}} \pm 0.03$ & $84.41^{\mathrm{c}} \pm 0.06$ & $76.78^{d} \pm 0.10$ & $87.89^{a} \pm 0.18$ & $85.67^{b} \pm 0.12$ \\
\hline $\begin{array}{l}\text { 9-Cis- } \beta \text {-carotene } \\
(\mu \mathrm{g} / \mathrm{g})\end{array}$ & $1.73^{\mathrm{d}} \pm 0.02$ & $1.93^{\mathrm{b}} \pm 0.05$ & $1.31^{\mathrm{e}} \pm 0.01$ & $2.99^{\mathrm{a}} \pm 0.01$ & $1.82^{\mathrm{c}} \pm 0.01$ \\
\hline $\begin{array}{l}\text { Vitamin A } \\
(\mathrm{RE} / 100 \mathrm{~g} \mathrm{Fw})\end{array}$ & 1230 & 1545 & 1388 & 1705 & 1568 \\
\hline
\end{tabular}

Values are mean $\pm \mathrm{SD}$. Means with different superscript in the same column are significantly different $(\mathrm{p}<0.05) \mathrm{VB}_{1}$ : Poultry manure at $5 \times 10^{3} \mathrm{~kg} / \mathrm{ha} ; \mathrm{VB}_{2}$ : Poultry manure at $2.5 \times 10^{3} \mathrm{~kg} / \mathrm{ha}+\mathrm{NPK}$ at $200 \mathrm{~kg} / \mathrm{ha}+$ Agrolyser at $2.7 \mathrm{~kg} / \mathrm{ha}, \mathrm{VB}_{3}$ : Agrolyser at $2.7 \mathrm{~kg} / \mathrm{ha}+\mathrm{NPK}$ at $200 \mathrm{~kg} / \mathrm{ha} ; \mathrm{VB}_{4}$ : Poultry manure at $5.0 \times 10^{3} \mathrm{~kg} / \mathrm{ha}+\mathrm{NPK}$ at $200 \mathrm{~kg} / \mathrm{ha}, \mathrm{VB}_{5}: \mathrm{NPK}$ 15:15:15 at $400 \mathrm{~kg} / \mathrm{ha}$ 
The lowest values for the two Cis-isomers, $3.17 \mu \mathrm{g} / \mathrm{g}$ and $1.31 \mu \mathrm{g} / \mathrm{g}$ for 13 -Cis- $\beta$-carotene and 9-Cis- $\beta$-carotene were obtained from samples grown on soil treated with Agrolyzer at $2.7 \mathrm{~kg} / \mathrm{ha} \mathrm{NPK}$ plus at $200 \mathrm{~kg} / \mathrm{ha}\left(\mathrm{VB}_{3}\right)$.

Table 3. Chromatogram data for Ipomea batatas (Variety UMUSPO 3) treated with poultry manure at $5 \mathrm{t} / \mathrm{ha}(\mathrm{VB} 1)$

\begin{tabular}{llllll}
\hline $\begin{array}{l}\text { Peak } \\
\text { Number }\end{array}$ & $\begin{array}{l}\text { Retention } \\
\text { time (min) }\end{array}$ & \%Area & $\begin{array}{l}\text { Peak } \\
\text { Number }\end{array}$ & $\begin{array}{l}\text { Retention } \\
\text { time (min) }\end{array}$ & \%Area \\
\hline 1 & 2,098 & 0,05 & 10 & 4,240 & 0,62 \\
2 & 2,847 & 0,05 & 11 & 4,502 & 3,44 \\
3 & 3,028 & 0,14 & 12 & 4,923 & 3,53 \\
4 & 3,140 & 0,31 & 13 & 5,228 & 12,39 \\
5 & 3,424 & 0,94 & 14 & 5,896 & 75,62 \\
6 & 3,567 & 0,10 & 15 & 6,620 & 1,89 \\
7 & 3,751 & 1,13 & 16 & 7,227 & 0,08 \\
8 & 3,937 & 1,53 & 17 & 8,052 & 0,08 \\
9 & 4,133 & 0,09 & & & \\
\hline
\end{tabular}

Table 3 shows the data for the UMUSPO 3 Ipomea batatas variety grown on soil subjected to poultry manure treatment at $5.0 \times 10^{3} \mathrm{~kg} / \mathrm{ha}\left(\mathrm{VB}_{1}\right)$. Seven out of seventeen eluted carotenoid fractions were identified and quantified. Trans- $\beta$-carotene predominated with $64.25 \mu \mathrm{g} / \mathrm{g}(73.62 \%)$ carotenoid content, followed by 13 -Cis- $\beta$-carotene $(0.81 \mu \mathrm{g} / \mathrm{g})(12.39 \%)$.

$\alpha$-carotene had the concentration of $(3.41 \mu \mathrm{g} / \mathrm{g})(3.53 \%), \beta$-cryptoxanthin had $3.09 \mu \mathrm{g} / \mathrm{g}$ (3.44\%), 9-Cis- $\beta$-carotene had $1.73 \mu \mathrm{g} / \mathrm{g}$ (1.89\%), zeaxanthin had $1.53 \mu \mathrm{g} / \mathrm{g}(1.53 \%)$, while lutein recorded $1.15 \mu \mathrm{g} / \mathrm{g}(1.13 \%)$. The higher carotenoid values of this variety (UMUSPO 3 ) correspond with their peak areas which seem to be higher than UMUSPO 1 Ipomea batatas variety.

Table 4. Chromatogram data for Ipomea batatas (Variety UMUSPO 3) treated with poultry manure at $2.5 \mathrm{t} / \mathrm{ha}$ plus NPK at $200 \mathrm{~kg} / \mathrm{ha}$ plus Agrolyser at $2.7 \mathrm{~kg} / \mathrm{ha}(\mathrm{VB} 2)$

\begin{tabular}{llllll}
\hline $\begin{array}{l}\text { Peak } \\
\text { Number }\end{array}$ & $\begin{array}{l}\text { Retention } \\
\text { time (min) }\end{array}$ & \%Area & $\begin{array}{l}\text { Peak } \\
\text { Number }\end{array}$ & $\begin{array}{l}\text { Retention } \\
\text { time (min) }\end{array}$ & \%Area \\
\hline 1 & 2,130 & 0,17 & 8 & 4,493 & 7,31 \\
2 & 2,806 & 0,07 & 9 & 4,912 & 2,63 \\
3 & 3,117 & 0,48 & 10 & 5,218 & 3,18 \\
4 & 3,420 & 1,25 & 11 & 5,886 & 77,98 \\
5 & 3,729 & 2,23 & 12 & 6,609 & 1,72 \\
6 & 3,928 & 2,23 & 13 & 7,252 & 0,06 \\
7 & 4,235 & 0,55 & 14 & 8,022 & 0,05 \\
\hline
\end{tabular}

Table 4 shows the data for the UMUSPO 3 Ipomea batatas variety treated with poultry manure at $2.5 \times 10^{3} \mathrm{~kg} /$ ha plus NPK at $200 \mathrm{~kg} /$ ha plus Agrolyser $2.7 \mathrm{~kg} / \mathrm{ha}$. The total of fourteen carotenoid fractions eluted while seven were identified and quantified. The predominant trans- $\beta$-carotene had the concentration of $84.41 \mu \mathrm{g} / \mathrm{g}(77.98 \%) . \beta$-cryptoxanthin and 13-Cis- $\beta$-carotene followed with $7.95 \mu \mathrm{g} / \mathrm{g}(7.31 \%)$ and $3.56 \mu \mathrm{g} / \mathrm{g}(3.18 \%)$ concentrations respectively, while $\alpha$-carotene had $3.17 \mu \mathrm{g} / \mathrm{g},(2.63 \%)$, zeaxanthin had $3.00 \mu \mathrm{g} / \mathrm{g}(2.33 \%)$, Lutein yielded $2.85 \mu \mathrm{g} / \mathrm{g}(2.23 \%)$ and 9-Cis- $\beta$-carotene had $1.93 \mu \mathrm{g} / \mathrm{g}(1.72 \%)$ carotenoid concentrations. 
Table 5. Chromatogram data for Ipomea batatas (Variety: UMUSPO 3) treated with Agrolyser at $2.7 \mathrm{~kg} / \mathrm{ha}(\mathrm{VB} 3)$

\begin{tabular}{llllll}
\hline $\begin{array}{l}\text { Peak } \\
\text { Number }\end{array}$ & $\begin{array}{l}\text { Retention } \\
\text { time (min) }\end{array}$ & \%Area & $\begin{array}{l}\text { Peak } \\
\text { Number }\end{array}$ & $\begin{array}{l}\text { Retention } \\
\text { time (min) }\end{array}$ & \%Area \\
\hline 1 & 2,098 & 0,07 & 8 & 4,495 & 6,17 \\
2 & 2,812 & 0,06 & 9 & 4,915 & 2,41 \\
3 & 3,122 & 0,47 & 10 & 5,220 & 3,20 \\
4 & 3,423 & 1,11 & 11 & 5,892 & 80,76 \\
5 & 3,735 & 1,95 & 12 & 6,605 & 1,27 \\
6 & 3,932 & 2,00 & 13 & 7,256 & 0,06 \\
7 & 4,240 & 0,43 & 14 & 8,036 & 0,04 \\
\hline
\end{tabular}

Table 5 shows data for the UMUSPO 3 Ipomea batatas variety treated with Agrolyser at $2.7 \mathrm{~kg} / \mathrm{ha}$ plus NPK at $200 \mathrm{~kg} / \mathrm{ha}$. A total of fourteen carotenoids eluted and separated but only seven major carotenoids were identified and quantified. The predominant trans- $\beta$-carotene had the concentration of $76.78 \mu \mathrm{g} / \mathrm{g},(80.76 \%)$, followed by $\beta$-cryptoxanthin with $5.93 \mu \mathrm{g} / \mathrm{g}(6.17 \%)$, 13-Cis- $\beta$-carotene $3.17 \mu \mathrm{g} / \mathrm{g}(3.20 \%)$ concentration whereas $\alpha$-carotene, zeaxanthin, lutein and 9-Cis- $\beta$-carotene had $2.56 \mu \mathrm{g} / \mathrm{g}(2.41 \%), 2.25 \mu \mathrm{g} / \mathrm{g}(2.0 \%), 2.18 \mu \mathrm{g} / \mathrm{g}$. (1.95\%), and $1.31 \mu \mathrm{g} / \mathrm{g}$ $(1.27 \%)$ carotenoid contents. It is worthy to note that trans- $\beta$-carotene and its Cis-isomers accounted for about $85.23 \%$ of the total of the carotenoids leaving only $14.77 \%$ to other minor carotenoids.

Table 6. Chromatogram data for Ipomea batatas (Variety: UMUSPO 3) treated with poultry manure at $5 \mathrm{t} / \mathrm{ha}$ plus NPK at $200 \mathrm{~kg} / \mathrm{ha}(\mathrm{VB} 4)$

\begin{tabular}{llllll}
\hline $\begin{array}{l}\text { Peak } \\
\text { Number }\end{array}$ & $\begin{array}{l}\text { Retention } \\
\text { time (min) }\end{array}$ & \%Area & $\begin{array}{l}\text { Peak } \\
\text { Number }\end{array}$ & $\begin{array}{l}\text { Retention } \\
\text { time (min) }\end{array}$ & \%Area \\
\hline 1 & 2,81 & 0,04 & 8 & 4,49 & 5,84 \\
2 & 3,15 & 0,48 & 9 & 4,922 & 4,42 \\
3 & 3,42 & 1,30 & 10 & 5,224 & 9,80 \\
4 & 3,736 & 1,30 & 11 & 5,883 & 70,96 \\
5 & 3,934 & 1,38 & 12 & 6,617 & 2,34 \\
6 & 4,078 & 0,93 & 13 & 7,224 & 0,10 \\
7 & 4,235 & 0,70 & 14 & 8,038 & 0,09 \\
\hline
\end{tabular}

Table 6 is the data for the UMUSPO 3 Ipomea batatas variety treated with poultry manure at $5.0 \times 10^{3} \mathrm{~kg} /$ ha plus NPK at $200 \mathrm{~kg} / \mathrm{ha}$. The predominant Carotenoid fraction also trans- $\beta$-carotene followed by its 13-Cis-isomer. The former had the concentration $87.89 \mu \mathrm{g} / \mathrm{g}(70.96 \%)$, while the latter (13-Cis- $\beta$-carotene) had $12.36 \mu \mathrm{g} / \mathrm{g}(9.80 \%)$ concentration. $\beta$-cryptoxanthin had $7.32 \mu \mathrm{g} / \mathrm{g}(5.84 \%)$ concentration. Other fractions include; $\alpha$-carotene $(6.14 \mu \mathrm{g} / \mathrm{g})(4.42 \%), 9$-Cis- $\beta$-carotene $(2.99 \mu \mathrm{g} / \mathrm{g})$ $(2.34 \%)$, lutein $(2.37 \mu \mathrm{g} / \mathrm{g})(1.63 \%)$ and zeaxanthin $(2.03 \mu \mathrm{g} / \mathrm{g})(1.38 \%)$.

The peak area of trans- $\beta$-carotene fraction of this sample appears to be the highest of all the quantified Carotenoid fractions of UMUSPO 3 Ipomea batatas varieties under this study. The trans$\beta$-carotene and total $\beta$-carotene content of this Ipomea batatas sample were $87.45 \mu \mathrm{g} / \mathrm{g}$ and 103.23 $\mu \mathrm{g} / \mathrm{g}$ respectively. This was the highest carotenoid yield from all the treatments. Thus the application of poultry manures at $5.0 \times 10^{3} \mathrm{~kg} /$ ha plus NPK at $200 \mathrm{~kg} /$ ha gave the best carotenoid yield for UMUSPO 3 variety.

The chromatogram data of UMUSPO 3 Ipomea batatas variety treated with NPK 15:15:15 at $400 \mathrm{~kg} / \mathrm{ha}$ is shown in Table 7. A total of fourteen carotenoid peaks eluted. The seven identified carotenoids include trans- $\beta$-carotene which was predominant with the concentration of $85.67 \mu \mathrm{g} / \mathrm{g}$ (78.30\%), followed by $\beta$-cryptoxanthin $(7.76 \mu \mathrm{g} / \mathrm{g})(7.02 \%) ; 13$-Cis- $\beta$-carotene $(3.92 \mu \mathrm{g} / \mathrm{g})(3.51 \%)$, $\alpha$-carotene $3.28 \mu \mathrm{g} / \mathrm{g}(2.70 \%)$, zeaxanthin $(2.77 \mu \mathrm{g} / \mathrm{g})(2.20 \%)$, lutein $(2.77 \mu \mathrm{g} / \mathrm{g})(2.15 \%)$ and 9-Cis$\beta$-carotene $(1.82 \mu \mathrm{g} / \mathrm{g})(1.57 \%)$ fractions. 
Table 7. Chromatogram data for Ipomea batatas (Variety: UMUSPO 3) treated with NPK at $400 \mathrm{~kg} / \mathrm{ha}$ (VB5)

\begin{tabular}{llllll}
\hline $\begin{array}{l}\text { Peak } \\
\text { Number }\end{array}$ & $\begin{array}{l}\text { Retention } \\
\text { time (min) }\end{array}$ & \%Area & $\begin{array}{l}\text { Peak } \\
\text { Number }\end{array}$ & $\begin{array}{l}\text { Retention } \\
\text { time (min) }\end{array}$ & \%Area \\
\hline 1 & 2,130 & 0,016 & 8 & 4,500 & 7,02 \\
2 & & 0 & 9 & 4,923 & 2,70 \\
3 & 2,806 & 0,6 & 10 & 5,229 & 3,51 \\
4 & 3,113 & 0,48 & 11 & 5,912 & 78,30 \\
5 & 3,422 & 1,22 & 12 & 6,625 & 1,57 \\
6 & 3,733 & 2,15 & 13 & 7,279 & 0,08 \\
7 & 4,240 & 0,49 & 14 & 8,05 & 0,05 \\
\hline
\end{tabular}

Generally, the peak areas of UMUSPO 3 Ipomea batatas variety samples were higher than that of some other Ipomea batatas [27] samples showing that UMUSPO 3 OFSP potato samples is a very good source of pro vitamin A carotenoids (especially total $\beta$-carotene) $(76.76 \mu \mathrm{g} / \mathrm{g}-$ $103.23 \mu \mathrm{g} / \mathrm{g}$ ) The $\beta$-carotene values obtained in this study for the orange-fleshed sweet potato is lower than $218 \mu \mathrm{g} / \mathrm{g}$ in orange-fleshed sweet potato (Brazil cultivars) [22,28,29]. The findings support previous studies on the significant role of orange fleshed sweet potatoes to be utilized as a viable food-based strategy for controlling vitamin A deficiency [30].

The carotenoid concentration of some green leafy vegetables was found to be lower [31] but was significantly improved by cooking. Pterocarpus mildbreadii leaf contained a total $\beta$-carotene $(\mathrm{T} \beta-\mathrm{c})$ level that was significantly $(\mathrm{p}<0.05)$ higher in cooked $(212.44 \mu \mathrm{g} / \mathrm{gdwt})$ than in raw leaf $(83.53 \mu \mathrm{g} / \mathrm{gdwt})[32]$.

\section{Conclusion}

UMUSPO 3 OFSP potato samples is a very good source of pro vitamin A carotenoids (especially total $\beta$-carotene). The use of poultry manures at $5.0 \times 10^{3} \mathrm{~kg} / \mathrm{ha}$ plus NPK at $200 \mathrm{~kg} / \mathrm{ha}$ for soil management will promote carotenoid yield for UMUSPO 3 variety in utilsols of Southeast Nigeria and beyond. Soil nutrient management with Poultry manure at $2.5 \times 10^{3} \mathrm{~kg} / \mathrm{ha}+\mathrm{NPK}$ at $200 \mathrm{~kg} / \mathrm{ha}+$ Agrolyser at $2.7 \mathrm{~kg} / \mathrm{ha}$ gave the highest yield of beta cryptoxanthin (which provides only half of the amount of vitamin A that can be provided by the beta carotenes).

\section{Acknowledgement}

We are grateful to Prof. D.A. Okpara and his students for undertaking the field work, which preceded the present research work.

\section{References}

[1] WHO. Global Prevalence of Vitamin A deficiency in Populations at Risk 1995-2005 (2009) Geneva, Switzerland.

[2] G.J. Scott and L. Maldonado. CIP sweet potato facts. A compendium of key figure and analyses for 33 important sweet potato producing countries. Peru, Lima International Potato Centre (1996) (CIP).

[3] D.S. Mclaren, and M. Frigg. Sight and Life Manual on Vitamin A Deficiency Disorders (VADD) $2^{\text {nd }}$ Edition (2001) pp. 31.

[4] S. Mitra. Nutritional Status of Orange-Fleshed Sweet Potatoes in Alleviating Vitamin A Malnutrition through a Food-Based Approach. Journal of Nutrition \& Food Sciences, 2012 28. DOI: $10.4172 / 2155-9600.1000160$ 
[5] P.J. Van Jaarsveld et al. $\beta$-carotene-rich orange-fleshed sweet Potato improves the Vitamin A Status of Primary relative-Dose Response Test. American Journal of Clinical Nutrition. 81(2005) 1080-1087.

[6] R.S. Parker. Absorption Metabolism and Transport of Carotenoids. FASEB Journal. 10 (1996) 542-551.

[7] H. Giester. (1993). Anti-Carcinogenic Effect of Common Carotenoid. International Journal of Vitamin Nutrition Research. 63 (1993) 93-121.

[8] H. Van den Berg et al. "The Potential for the Improvement of Carotenoid Levels in Foods and the Likely Systemic Effects," Journal of the Science of Food and Agriculture, 80(7)(2000) 880-912. Doi: 10.1002/ (SICI) 1097-0010(20000515)80:7<880:AIDJSFA646>3.0.CO;2-1

[9] J.A. Woolfe, Sweet Potato: An Untapped Food Resource. Cambridge University Press, (1992) Cambridge, England, pp. 634.

[10] A.C. Bovell-Benjamin, and T.L. Steve. "Sweetpotato: A Review of Its Past Present and Future Role in Human Nutrition," Advances in Food Nutrition Research, Vol. 52, 2007, pp. 1-59. doi:10.1016/S1043-4526(06)52001-7

[11] F. Jailal, et al. Serum Retinol Concentration in Children are Affected by Food Sources of $\beta$ carotene, Fat Intake and Anthelminthic Drug Treatment. American Journal of Clinical Nutrition. 68 (1998) 623-629.

[12] E. Boy, A. Miloff, "Provitamin A Carotenoid Retention in Orange Sweet-potato," Sight and Life Magazine, 3 (2009), pp. 27-33

[13] IFPRI Synopsis. Global Hunger Index The Challenge of Hidden Hunger. IFPRI issue brief. 83 (2013).

[14] U.J. Ukpabi. Root and Tubers in Nigeria as Sources of Industrial Raw Materials. In: Nigeria Agro Raw Materials Development: Some Industrial Crops and Salient Issues RMDRC Publications, Abuja, 1(2009) 1-19.

[15] FAO

(2011).Statistical databasehttp://faostat.fao.org/site/567/DesktopDefault.aspx?PageID=567\#ancor $\quad$ (accessed October 7, 2012).

[16] SASHA/CIP (2009). Building the evidence base for sweet potato marketing in Nigeria. http://www.cipotato.org/sasha/08 html (accessed on January $12^{\text {th }}, 2010$ ).

[17] N. Zuraida, (2003). Sweet potato as an alternative food supplement during rice storage. Journal Lubang Pertanian. 22(4) (2003)150-155.

[18] T. Belehu (2003). Effect of planting density and Cultivar on yield and yield components of sweet potato in Ethiopia. University of Pretoria Ed. Chapter 8

[19] D.B. Rodriguez-Amaya, M.H. Kimura. Harvest-Plus Handbook for Carotenoid Analysis (2004) Harvest Press. Washington D. C. and Cali Columbia

[20] J.A. Howe, S.A.Tanumihardjo. Evaluation of Analytical Methods for Carotenoid Extraction from Biofortified maize (Zea mays spp.). Journal of Agriculture and Food Chemistry 54 (21) (2006) 7992-7997.

[21] D.B. Rodriguez-Amaya. Carotenoids and Food Preparation: The Retention of Pro-Vitamin A Carotenoids in Prepared, Processed and Stored Foods Opportunities for Micronutrients Intervention, 1997. 
[22] A.N. Ukom, P.C. Ojimelukwe, E.O. Alamu. All trans-Cis $\beta$-carotene of Selected Sweet Potato (Ipomea batatas L) Varieties as influenced by Different Levels of Nitrogen Fertilizer Application. African Journal of Food Science. 5 (2011) 131-137

[23] D.B. Rodriguez-Amaya. Nature and Distribution of Carotenoids in Foods. In:Charalambous, G. (Ed). Shelf-life Studies of Foods and Beverages.

[24] A.Chattopadhyay, et al. Compositional Changes of sweet potato as influenced by cultivar, harvest date and cooking. Acta Horticultura 703 (2006) 211-218.

[25] O.O. Kalu, P.C. Ojimelukwe, A.N. Ukom. Evaluation of the Effect of Planting Distance and Harvesting Time on the Carotenoids and Phytochemicals of Selected Orange-Fleshed Sweet Potato Varieties. International Letters of Natural Sciences. 66 (2017) 17-26

[26] P. C. Ojimelukwe, A.N. Ukom, O.O. Kalu. Contribution of planting space and harvesting period on the nutrient compositions of some OFSP sweet potato varieties grown in Southeast Nigeria ultisol. Journal of Nutrients 4 (1) (2018) 1-9

[27] L.S. Ndah, P.C. Ojimelukwe. 2018. Effect of Planting Space on Carotenoid Content and Carotenoid Profile of Two Orange Fleshed Sweet Potato Varieties. Journal of Plant Sciences and Crop Protection 1(2) (2018) 205-213.

[28] L.B. Almeida-Muradian, M.V.C. Penteado. Carotenoid and Provitamin A Value of Some Brazilian Sweet Potato Cultivars (Ipomea batatas L) Rev. Farm. Bioquim University of Sau Paulo. 28 (1992): 145-154.

[29] V. Vaida. "Vitamin A food production and use in Nepal" In: empowering Vitamin A foods. E. Wasantwisnt and G. A. Attig (Eds). Bangkok: Institute of Nutrition (1995) 29-44.

[30] S.M. Laurie, M Faber, N. Claasen. Incorporating orange-fleshed sweet potato into the food system as a strategy for improved nutrition: The context of South Africa. Food Research International 104 (2018)77-85. https://doi.org/10.1016/j.foodres.2017.09.016

[31] U. Kidmose et al. "Content of Carotenoids in Commonly Consumed Asian Vegetables and Stability and Extractability during Frying," Journal of Food Composition and Analysis, 19 (67) (2006) 562-571. doi:10.1016/j.jfca.2006.01.011

[32] F. E. Okpalanma, P. C. Ojimelukwe, D. Akachukwu, D. Post-Harvest Storage andProcessing Changes in Carotenoids, Chlorophylls, and Micronutrients in Pterocarpus mildbraedii. AASCIT Journal of Biology 2 (1) (2016)1-9. 